\title{
Community College Librarians and the ACRL Framework: Findings from a National Study
}

\section{Susan Wengler and Christine Wolff-Eisenberg}

\begin{abstract}
This study explored community college librarians' engagement with the Framework for Information Literacy for Higher Education. A national online survey with 1,201 community college librarian respondents reveals limited familiarity with and integration of the Framework into community college instruction to date. Findings indicate an openness to future adoption, as well as substantial interest in targeted professional development and a version of the Framework adapted for community college campuses. These results contribute benchmark instructional data on an understudied section of academic librarianship and add to the growing body of research on how librarians have updated teaching practices in response to the Framework.
\end{abstract}

\section{Introduction}

Nearly 9 million students attend community colleges year-round in the United States, with a disproportionate percentage coming from underrepresented populations and more than twothirds underprepared for higher education. ${ }^{1}$ Information literacy (IL) instruction is delivered to these students by community college librarians, and many community college librarians look to the Association of College and Research Libraries (ACRL) as a leading organization of higher education librarians in the United States for direction and guidance to inform their teaching practices.

In January 2016, ACRL replaced its Information Literacy Competency Standards for Higher Education (Standards) with the Framework for Information Literacy for Higher Education (Framework). ${ }^{2}$ While the Framework is intended for use by all types of higher education institutions, the often remedial reading, writing, and IL skills of the vulnerable community college student population may challenge community college librarians when integrating the more advanced and theoretical Framework into their instructional work. According to Reed, "For librarians who work with students on advanced research and high-level projects, the Framework will feel like a natural fit, whereas those who focus the great amount of their time on introductory concepts may struggle to see much relevance." ${ }^{3}$ This study seeks to investigate the Framework's fit and relevance on community college campuses through an exploration of community college librarians' familiarity with, use of, and attitudes toward the document.

\footnotetext{
*Susan Wengler is Assistant Professor at Queensborough Community College, The City University of New York; email: susan.teresa.wengler@gmail.com. Christine Wolff-Eisenberg is Manager, Surveys and Research, at Ithaka S+R; email: christine.m.wolff@gmail.com. (02020 Susan Wengler and Christine Wolff-Eisenberg, AttributionNonCommercial (http://creativecommons.org/licenses/by-nc/4.0/) CC BY-NC.
} 


\section{Literature Review}

Since its development and subsequent adoption in 2016, the larger academic library profession has greeted the Framework with a mix of confidence ${ }^{4}$ and suspicion. ${ }^{5}$ Some of the skeptics have situated their concerns within the conversation of power and privilege in higher education. Battista et al. find the document noticeably lacking in language that explicitly connects IL to civic engagement and social justice; ${ }^{6}$ Saunders suggests that the Framework should be amended to include an "information social justice" frame. ${ }^{7}$ Bombaro observes two distinct groups emerging in the Framework debate: "philosopher librarians" concerned with "highly theoretical perspectives" and "practical librarians" focused on "applying the Framework in concrete ways"; the author deems investing in Framework understanding to be a "luxury" and declares the document and by extension the academic library profession to be "elitist." ${ }^{8}$

As the Framework was drafted, reviewed, revised, and ultimately adopted, opinion-based discussions of its suitability for community college campuses appeared in the library and information science (LIS) literature. Craven argues that ACRL leadership disregarded community college librarian interests and input during the Standards/Framework process and that the Framework does not acknowledge or affirm the "generally recognized, measurable information literacy skills" that are necessary in the "results-driven environment" of community colleges. ${ }^{9}$ Dempsey et al. cite an instance at Raritan Valley Community College where faculty pushed back against the Framework for being "irrelevant to the work done by community college students." ${ }^{10}$ And, noting that the Framework has "generated confusion... particularly among community colleges ... that find it difficult to relate to a document full of theory and jargon, with no explicit practical application," Reed recommends that teaching community college librarians concentrate only on those two frames that may have relevance in their classrooms: "Research as Inquiry" and "Searching is Strategic."11

However, not all Framework feedback from community college library literature has been negative. Swanson reports the potential for introducing the Framework directly to classroom faculty through professional development workshops, describing the experience at Moraine Valley Community College as "eye opening ... and [offering] a new avenue to discuss student learning"; ${ }^{12}$ he also argues that, relative to the Standards, the Framework is "a better fit for community colleges ... a more honest approach as a national structure upon which to demonstrate value by measuring learning within and across libraries."13

Research by discipline, by geography, and across all academic library types reveals that Framework integration into IL instruction has not been universal to date. In a 2016 survey of health science librarians in academic and hospital library settings, Schulte and Knapp found that, while 52 percent of the 130 respondents were familiar with the Framework, only 11 percent used the document in instruction; 35 percent reported not currently using but planning to, and 54 percent reported not currently using and having no plans to. Twenty-four percent of respondents were ACRL members. ${ }^{14}$

Charles' 2016 survey of 34 New Jersey academic librarians assessed campus readiness to adopt the Framework; study subjects were limited to only those librarians in IL coordinator positions. ${ }^{15}$ And, while the survey was distributed to librarians at both community colleges and four-year institutions, study results are reported in aggregate and are not differentiated by institute type. While 50 percent of respondents had begun work on Framework implementation with fellow librarians, 65 percent did not feel fully confident with the Framework. ${ }^{16}$ Charles concludes that "an investigation on the readiness of librarians nationwide or in 
another state would be appropriate to provide a broader understanding of the progress being made." 17

Julien, Gross, and Latham's spring 2016 survey of US academic librarians found that, among its 622 respondents, 41 percent reported that the Framework has had "minor influence on my instruction" or "does not inform my instruction at all," while 31 percent indicated "significant influence." ${ }^{18}$ While study findings did differentiate university librarians from college or technical institute librarians, no distinction was made between two-year and fouryear colleges in the data reporting. In 15 follow-up interviews, participants revealed that the Framework has generated numerous positive outcomes, including perceived enhancement of teaching practice as well as increased collaboration and research opportunities..$^{19}$ Time constraints and the limitations of one-shot instruction were identified as obstacles to Framework adoption..$^{20}$ Three of the 15 interviewees were employed by community colleges; two of these three stated they were relatively unfamiliar with the Framework prior to study participation. ${ }^{21}$ Qualitative findings did not differentiate between institution type.

Community college-specific case studies have explored integration of the Framework into discipline-specific IL curriculum, including community health and developmental reading. ${ }^{22}$ However, no published studies were found that assessed community college librarian engagement with the Framework using survey techniques.

As outlined in its recent "Academic Library Impact" report, ACRL's research agenda suggests inquiry into how librarians have updated their instruction based on the Framework; separately, the report makes note of the lack of research on community colleges and community college librarianship. ${ }^{23}$ Findings from this investigation seek to address these research gaps, with a particular focus on underrepresented community college students and understudied community college librarians.

\section{Methodology}

\section{Study Population}

The population under study was degreed librarians employed at two-year public and private colleges in the United States who provide IL instruction as part of their current job responsibilities. "Degreed librarians" were defined as individuals with a master's and/or a doctorate in LIS. "Two-year colleges" were defined as community colleges, junior colleges, and technical colleges included in select 2018 Carnegie Classifications; 1,408 institutions met these criteria. See appendix A for a list of included Carnegie Classification categories.

A list of community college librarian and library director email addresses was handgathered from these 1,408 institutional websites. In total, 4,284 contacts were collected, composed of 3,467 individual librarians, 748 library directors, and 69 general library inboxes (like info@communitycollege.edu). General library inboxes were included when no individual contact information was discernible; when librarians were not differentiated from other staff, all library employee emails were included. These numbers approximate the National Center for Education Statistics' most recent estimates of 4,102 FTE librarians employed by 1,304 community colleges in the United States. ${ }^{24}$

\section{Survey Design}

A web-based instrument titled "Survey of Community College Librarians" was developed using SurveyMonkey; see appendix B for the complete survey. The instrument included four 
forced-response questions followed by 40 closed-ended optional questions and two openended optional questions. The forced-response questions included informed consent provision and confirmation of study population criteria, including employment in a two-year college library, holding an advanced LIS degree, and providing IL instruction as part of current job responsibilities. Participants who replied negatively to these questions were disqualified, ending their sessions. The closed- and open-ended questions focused on subjects' knowledge, attitudes, behaviors, and feelings related to the Framework and on subjects' demographic variables. Survey respondents interested in being contacted for follow-up phone interviews were asked to provide their name and email address. The survey was estimated to take approximately 10 minutes to complete.

The survey was pretested via cognitive interviews prior to national distribution. Pretesting allowed for the refinement of draft questions; verbal information about the survey responses was collected and used to determine whether the questions generated the intended information. ${ }^{25}$ Pretesting also enabled the development of new survey questions based on areas of interest not previously explored. Pretesting participants were recruited via an email sent to members of ACRL's Community and Junior College Libraries Section (CJCLS) committees. From those who responded as interested in participating, 10 persons were selected to represent a variety of perspectives including institution size, institution geography, and librarian role. After completing the online survey draft, they engaged in a half-hour phone interview and received a \$25.00 Amazon.com gift card for their participation.

The study received approval from the University Integrated Institutional Review Board of The City University of New York (Protocol 2018-0905).

\section{Survey Distribution}

The survey was deployed via multimodal distribution including through SurveyMonkey, direct email, and listservs. Individual librarians $(3,467)$ received an invitation to participate and a unique link to the survey via SurveyMonkey. Library directors (748) and general library addresses (69) received an invitation to participate and a link to the survey via the Principal Investigator's institutional email; this correspondence included a request to share with appropriate library employees. The survey was also sent out via selected ACRL membership listservs, including the ACRL Framework for Information Literacy for Higher Education listserv (acrlframe@lists.ala.org); the ACRL CJCLS Section listserv (cjcls-1@lists.ala.org); and the Information Literacy Instruction Discussion listserv (ill-1@lists.ala.org).

The survey launched on September 20, 2018, and closed on November 1, 2018. Reminders were sent on October 11 and October 24, 2018. Invitation and reminder messages indicated that the survey was on the teaching practices of community college librarians; the authors intentionally positioned the study in this broad manner to gather a variety of perspectives on the Framework and not only elicit response from those who were most engaged with it. Survey participation was encouraged through incentives. Respondents could enter a drawing to win one of three $\$ 100.00$ Amazon.com gift cards; this prize entry form was kept separate from participants' survey responses. Survey responses in which the participant indicated interest in being contacted about a follow-up interview have been kept confidential; survey responses in which the participant was not interested in being contacted remain anonymous, as no personally identifiable information was collected. 


\section{Results}

\section{Respondent Demographics}

In total, 1,201 valid, completed responses were received from qualified respondents. Assuming the study population is composed of 4,284 individuals, this constitutes a response rate of 28 percent.

Fifty-eight percent (690) of respondents reported being a community college librarian for six or more years; 42 percent (508) reported being a community college librarian for five years or less. The mean number of years since receiving a LIS master's or doctoral degree is 15 years.

Seventy-nine percent (947) reported their employment status as full-time; 18 percent (210) reported their employment status as part-time and 3 percent (40) reported their employment status as neither part-time nor full-time. The largest proportion $(54 \%, 642)$ indicated current tenure status as nontenured and not on a tenure track; 25 percent (297) indicated tenured status; 14 percent (169) indicated nontenured and on tenure track; and 7 percent (82) indicated none of these statuses.

Eighty-six percent $(1,029)$ of respondents identified as not a library dean, director, or chief officer; 14 percent (169) identified as a library dean, director, or chief officer. Sixty-one percent (731) of respondents were not members of ACRL; 33 percent (399) were members of ACRL and 6 percent (67) reported that they did not know or were not sure.

In response to one of the Likert scale questions, 90 percent $(1,082)$ strongly agreed or somewhat agreed with the statement, "I enjoy teaching information literacy at my community college." Six percent (69) strongly disagreed or somewhat disagreed with the statement; 4 percent (49) neither agreed nor disagreed with the statement.

Most respondents reported teaching between 31 and $50(21 \%), 50$ and $100(20 \%)$, or 1 and $10(19 \%)$ IL sessions in the last 12 months. Sessions included all types of instruction (for example: one-shots, multiple shots, credit-bearing courses, workshops) that have taken place in person and/or online. These data are summarized in table 1 below.

Ninety-seven percent of respondents $(1,163)$ reported providing one-shot instruction in the last 12 months as contrasted with 48 percent (573) providing multiple-shots, 43 percent (522) providing workshops, and 19 percent (228) providing credit-bearing instruction.

The largest proportion $(29 \%, 327)$ of respondents work in community colleges with enrollment of 2,000 4,999 FTE students; 27 percent (310) work in institutions with 5,000-9,999 FTE students; 25 percent (282) work in institutions with 10,000 or more FTE students; 17 percent (192) work in institutions with 500-1,999 FTE students; and 2 percent (24) work in institutions with fewer than 500 FTE students. These data are summarized in table 2. A strong positive relationship exists between the number of community college contacts from institutions of each size and the number of respondents from institutions of each size $(r=.99)$.

\begin{tabular}{|l|c|c|}
\hline \multicolumn{3}{|c|}{$\begin{array}{c}\text { TABLE 1 } \\
\text { “How many information literacy } \\
\text { instruction sessions did you teach } \\
\text { in the last 12 months?" }\end{array}$} \\
\cline { 2 - 3 } & \multicolumn{2}{|c|}{ Responses } \\
\cline { 2 - 3 } & Frequency & Percentage \\
\hline 0 & 10 & $1 \%$ \\
\hline $1-10$ & 231 & $19 \%$ \\
\hline $11-20$ & 189 & $16 \%$ \\
\hline $21-30$ & 190 & $16 \%$ \\
\hline $31-50$ & 256 & $21 \%$ \\
\hline $50-100$ & 235 & $20 \%$ \\
\hline $101+$ & 69 & $6 \%$ \\
\hline I don't know & 16 & $1 \%$ \\
\hline Total & 1,196 & $100 \%$ \\
\hline
\end{tabular}




\begin{tabular}{|l|c|c|c|c|}
\hline \multicolumn{5}{|c|}{ TABLE 2} \\
& Survey Respondents & \multicolumn{2}{c|}{ Invitees } \\
\cline { 2 - 5 } & Frequency & Percentage & Frequency & Percentage \\
\hline Less than 500 FTE students/Very small & 24 & $2 \%$ & 152 & $3 \%$ \\
\hline $500-1,999$ FTE students/Small & 192 & $17 \%$ & 639 & $15 \%$ \\
\hline $2,000-4,999$ FTE students/Medium & 327 & $29 \%$ & 1,334 & $31 \%$ \\
\hline $5,000-9,999$ FTE students/Large & 310 & $27 \%$ & 1,177 & $27 \%$ \\
\hline 10,000 or more FTE students/Very large & 282 & $25 \%$ & 1,062 & $24 \%$ \\
\hline Total & 1,135 & $100 \%$ & 4,364 & $100 \%$ \\
\hline $\begin{array}{l}\text { Please note: The total number of invitees presented in this table differs slightly from that presented } \\
\text { within the body of this article; the total invitees presented in the body of the article has taken into }\end{array}$ \\
account minor edits made to the distribution list while the survey was in the field. \\
\hline
\end{tabular}

Completed surveys were received from 48 states; no completed surveys were received from the District of Columbia, Puerto Rico, South Dakota or West Virginia. A strong positive relationship exists between the number of community college contacts gathered for each state and the number of respondents from that state $(r=.99)$. See appendix $C$ for frequency and percent of completed surveys by state.

\section{Familiarity with Framework}

The authors considered reading the Framework as a baseline measurement of engagement and familiarity. A majority of respondents $(59 \%, 705)$ reported having read all of the Framework; however, 31 percent (369) had read only a part of the Framework and 9 percent (109) had not read the Framework. A number of open-ended question responses indicated that the survey instrument itself served as the initial introduction to the Framework for some respondents.

Only 11 percent (135) of respondents strongly agreed with this statement: "I am very familiar with the frames, knowledge practices, and dispositions in the ACRL Framework"; another 38 percent (452) somewhat agreed, and 31 percent (369) somewhat or strongly disagreed. Not knowing the Framework exists and not reading the Framework are two explanations for a lack of familiarity with the document. Additional insights into possible barriers to understanding the Framework - as distinguished from barriers to implementation - were provided in an openended question where the Framework's language and construction were cited as problematic by a number of respondents. As one respondent explained, "I attended a workshop to help wrap my head around the new framework, and felt somewhat overwhelmed by it. There are aspects of it that are very exciting and innovative, but at the same time it feels convoluted, academic, and less accessible."

Roughly one in 10 respondents $(11 \%, 129)$ provided feedback on the Framework while it was being developed and revised by ACRL. Community college librarians may not have been aware of Framework development and feedback opportunities and/or they may have been aware but chose not to participate. Comments in an open-ended question underscored a feeling of not having been heard or included in the document creation. As one participant who was involved in the development process described, "... ACRL ramrodded the Framework through and paid NO attention to community college concerns. I know because I was at those meetings. The Framework is for university librarians who don't have enough to do." 
Another respondent expressed this sentiment: "The reality is that community colleges help a huge number of underrepresented populations who are already experienc[ing] daily disparities in their lives, whether [it] is race, gender, economic class, or sexuality. It's obvious to anyone who works at a community college or a trade college that the Frameworks was written and pushed by a limited group of librarians with a small understand[ing] or consideration of this."

\section{Attitudes toward Framework}

Survey respondents are likely to consider the Framework germane to two-year institutions. Sixty-seven percent (806) somewhat agreed or strongly agreed with this statement: "The ACRL Framework is relevant to information literacy instruction on community college campuses." However, in open-ended responses, positive comments regarding the Framework's relevance focused on professional roles and identities generally; no positive comments referenced community college campuses specifically. For example, one respondent indicated, "I believe it gives me the professional backing to go beyond the skills-based one-shot, which neither I nor students enjoy or benefit from. The value placed on critical thinking over tools gives me common ground with teaching faculty across the campus, and I can work towards being a teacher, not the EBSCO demo lady." This sentiment contrasts with the negative perspectives discussed later regarding the community college setting as being problematic to Framework implementation.

When respondents were asked about the importance of each frame to their information literacy instruction, some differentiation was revealed among the six constructs. Roughly 7 in 10 respondents indicate that "Scholarship as Conversation" and "Information Creation as a Process" are somewhat or very important as contrasted with approximately 8 or 9 in 10 respondents indicating the same level of importance for the four other frames. See table 3 for a summary of results.

\begin{tabular}{|c|c|c|}
\hline \multicolumn{3}{|c|}{$\begin{array}{l}\text { TABLE } 3 \\
\text { "How important or unimportant are each of the following frames from the ACRL } \\
\text { Framework for your information literacy instruction?" Percent of respondents who } \\
\text { indicated that each is somewhat or very important. }\end{array}$} \\
\hline & \multicolumn{2}{|c|}{ Responses } \\
\hline & Frequency & Percentage \\
\hline Authority Is Constructed and Contextual & 954 & $80 \%$ \\
\hline Information Creation as a Process & 869 & $73 \%$ \\
\hline Information Has Value & 1,017 & $86 \%$ \\
\hline Research as Inquiry & 1,031 & $87 \%$ \\
\hline Scholarship as Conversation & 811 & $68 \%$ \\
\hline Searching as Strategic Exploration & 1,039 & $87 \%$ \\
\hline
\end{tabular}

A vast majority of respondents $(78 \%, 933)$ somewhat agree or strongly agree with the statement, "I would value a version of the ACRL Framework adapted for community colleges"; of these respondents, 48 percent (576) strongly agreed with the statement. See figure 1 for a summary of responses. 


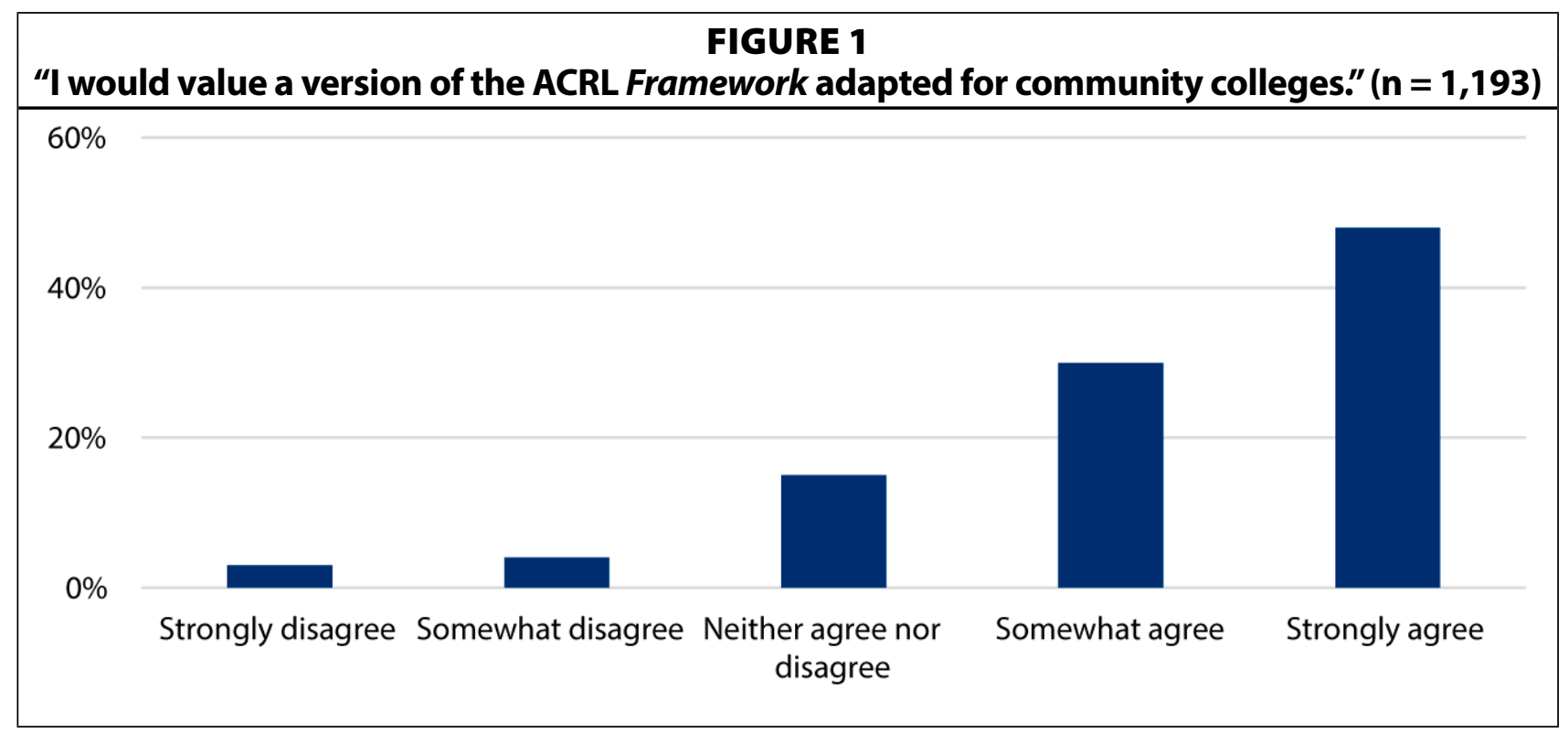

In an open-ended question, respondents expressed enthusiasm for a document modified specifically for two-year colleges. "I think it's an incredible idea to develop a cc-version of the Framework," notes one participant. "The nature of cc librarianship is hectic, diffuse, and overworked... [and] our students are very different from those at 4-years and require different pedagogical methods, scaffolding, and support. I would love to participate in this." Another respondent shares, "I think a more useful tool, especially for CC librarians, would be a tool that shows the progression of skill development along a continuum from novice through developing skill toward proficiency and expertise."

\section{Use of Framework} Instruction

The Framework has not sparked widespread changes in community college teaching practices to date. Only 10 percent (120) of respondents have altered their information literacy instruction "a great extent" as a result of the Framework; 35 percent (415) have made moderate alteration; 32 percent (386) have made small alterations, and 23 percent (280) have made no alterations. See figure 2 for all results.

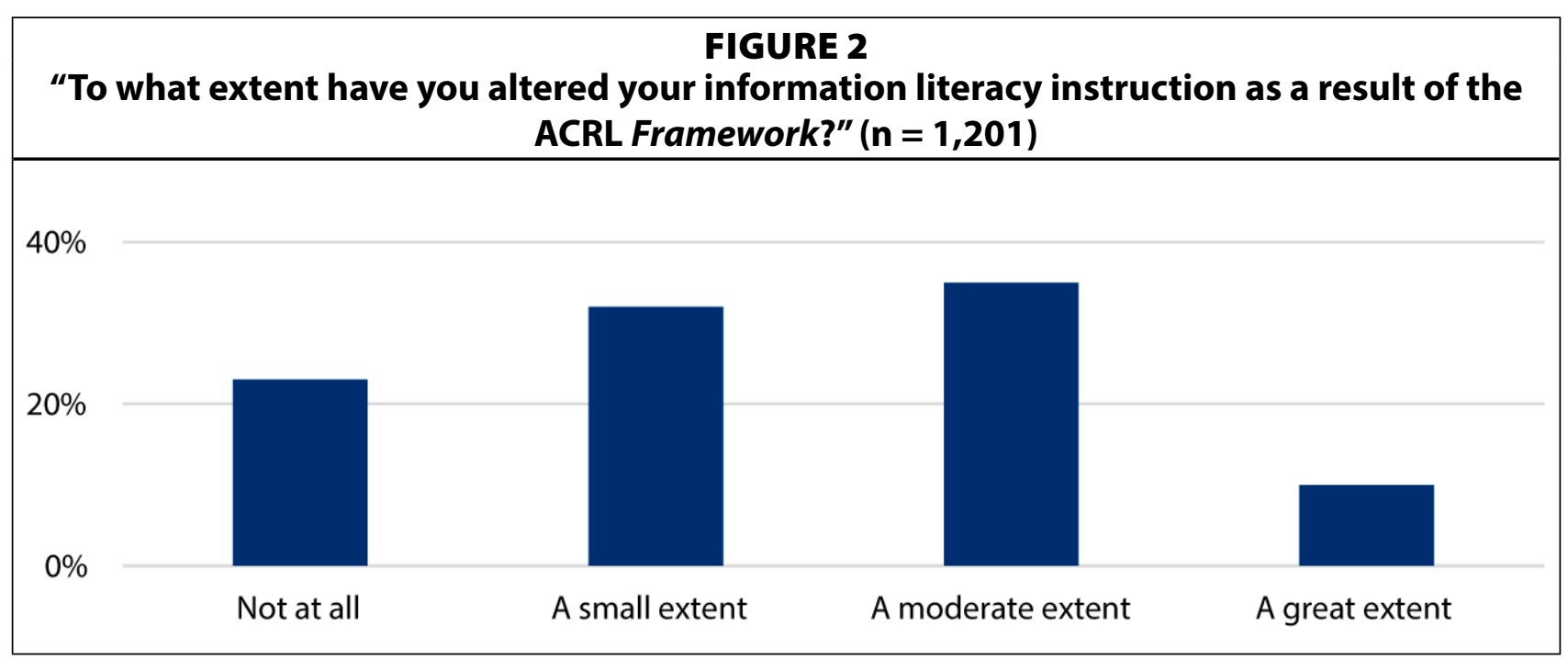


Both the adopter group - that is, those who have altered their instruction to any degreeand the nonadopter group-those who have not altered their instruction at all-show a strong appetite for future Framework engagement. Of those respondents who had already adopted the Framework in practice, a large majority $(79 \%, 729)$ indicated that they were interested in further integration. Of those respondents who had not adopted the Framework in any way, roughly half $(46 \%, 130)$ indicated that they were interested in doing so.

However, survey respondents were unlikely to view Framework use as being important to career progress. A majority of respondents $(52 \%, 622)$ somewhat or strongly disagreed with this statement: "Incorporating the ACRL Framework into my information literacy instruction is important to advancement, promotion, or contract renewal in my current position"; 32 percent (377) neither agreed nor disagreed.

A majority of adopters $(58 \%, 529)$ agreed that the Framework has improved their instruction. In an open-ended question, respondents credited the Framework with providing inspiration to their teaching design and practice. One librarian expressed the following sentiment: "The Framework has bolstered my courage to take a radically different approach to how we design and deliver our information literacy instruction. I understand that students are more responsive to instruction when it directly relates to their assignment but that usually means just providing a tour through applicable databases. After [number] years as an instructional librarian, the framework has helped me understand that what I should have been teaching were the threshold concepts underlying information literacy to help students build a solid foundation about how to think about the information gathering, application, and evaluation process." Another states, "Teaching with the framework in mind provides a context for teaching information literacy skills and has made my work more meaningful. Student engagement has risen, along with the quality of class discussions."

Respondents who indicated that they are members of ACRL are more likely to have been involved in the development and revision of the Framework, to have read the Framework, and to have altered their instruction based on the Framework compared to those who are not members of ACRL. Eighteen percent (70) of ACRL member respondents indicated that they were involved in one or more activities related to the development and revision of the Framework, compared to 7 percent of nonmembers (52). Seventy-four percent of ACRL member respondents have read all of the Framework (297) compared to 51 percent of nonmembers (372). Finally, 13 percent (53) of ACRL member respondents indicated incorporation of the Framework into their instruction to a great extent compared to 8 percent (58) of nonmembers; likewise, 14 percent (56) of members reported not having altered their instruction based on the Framework at all compared to 28 percent of nonmembers (206).

\section{Campus Conversations}

Survey respondents were fairly even in agreement and disagreement that the Framework has created opportunities for campus conversation, with 38 percent (460) somewhat or strongly agreeing and 31 percent (376) somewhat or strongly disagreeing. When community college librarians do discuss the Framework, they are doing so with their library colleagues but rarely with groups outside their department. A summary of responses is included in table 4. 


\begin{tabular}{|c|c|c|c|c|c|c|c|c|c|c|c|c|}
\hline \multicolumn{13}{|c|}{$\begin{array}{l}\text { TABLE } 4 \\
\text { “How often do you reference the ACRL Framework in conversations with each of the } \\
\text { following at your community college?" }\end{array}$} \\
\hline & \multicolumn{2}{|c|}{ Never } & \multicolumn{2}{|c|}{ Rarely } & \multicolumn{2}{|c|}{ Sometimes } & \multicolumn{2}{|c|}{ Often } & \multicolumn{2}{|c|}{ Always } & \multicolumn{2}{|c|}{ N/A } \\
\hline & $\mathbf{n}$ & $\%$ & $\mathbf{n}$ & $\%$ & $\mathbf{n}$ & $\%$ & $\mathbf{n}$ & $\%$ & $\mathbf{n}$ & $\%$ & $\mathbf{n}$ & $\%$ \\
\hline $\begin{array}{l}\text { Classroom } \\
\text { faculty }\end{array}$ & 403 & $34 \%$ & 200 & $17 \%$ & 319 & $27 \%$ & 160 & $14 \%$ & 41 & $3 \%$ & 62 & $5 \%$ \\
\hline $\begin{array}{l}\text { Writing Center } \\
\text { staff }\end{array}$ & 590 & $50 \%$ & 189 & $16 \%$ & 125 & $11 \%$ & 56 & $5 \%$ & 24 & $2 \%$ & 207 & $17 \%$ \\
\hline $\begin{array}{l}\text { Center for } \\
\text { Teaching \& } \\
\text { Learning staff }\end{array}$ & 449 & $38 \%$ & 192 & $16 \%$ & 181 & $15 \%$ & 78 & $7 \%$ & 24 & $2 \%$ & 269 & $23 \%$ \\
\hline $\begin{array}{l}\text { Curriculum } \\
\text { committee(s) }\end{array}$ & 516 & $43 \%$ & 169 & $14 \%$ & 144 & $12 \%$ & 67 & $6 \%$ & 22 & $2 \%$ & 271 & $23 \%$ \\
\hline $\begin{array}{l}\text { Librarians, } \\
\text { library } \\
\text { administrators, } \\
\text { and library staff }\end{array}$ & 156 & $13 \%$ & 147 & $12 \%$ & 368 & $31 \%$ & 310 & $26 \%$ & 169 & $14 \%$ & 47 & $4 \%$ \\
\hline $\begin{array}{l}\text { Administrators } \\
\text { (such as } \\
\text { president, } \\
\text { provost, deans) }\end{array}$ & 504 & $42 \%$ & 235 & $20 \%$ & 193 & $16 \%$ & 69 & $6 \%$ & 15 & $1 \%$ & 179 & $15 \%$ \\
\hline $\begin{array}{l}\text { Tutoring } \\
\text { Center staff }\end{array}$ & 633 & $53 \%$ & 188 & $16 \%$ & 106 & $9 \%$ & 53 & $4 \%$ & 18 & $2 \%$ & 196 & $16 \%$ \\
\hline
\end{tabular}

A number of respondents referenced the potential of using the Framework to facilitate conversations with nonlibrary administration and faculty. One librarian explained, "The language and focus of Framework has allowed us to create deeper collaborations with our Writing Center, tutors, and faculty in various programs across campus ... It's been a great relief to not use standards as a check box but rather to focus our efforts on an approach to teaching and learning. Before I retire I hope that the phrase 'just show students the databases' is no longer used." Conversely, some survey respondents specifically noted that the Framework does not enhance conversations with nonlibrary administration and faculty; one respondent articulated this statement: "I'm lucky if faculty will give me the time to tell their class how to navigate to the Library webpage, much less talk about inquiry and conversation and all that. If I went that route, it would be the fastest way to STOP doing ANY IL instruction."

\section{Deterrents to Use}

Only 37 percent (446) of survey respondents felt it is easy to integrate the Framework into community college instruction. An absence of preparation and instructional time appears to be one barrier to Framework use. Almost half $(49 \%, 586)$ of survey respondents somewhat agreed or strongly agreed with the statement, "I do not have enough time to adequately incorporate the 
ACRL Framework into my information literacy instruction"; only 24 percent (288) somewhat or strongly disagreed with this statement. That said, 55 percent (662) agreed that the time it takes to implement integration is worthwhile.

In an open-ended question, a range of feelings were expressed that might account for low implementation, including perceptions of elitism, the unique needs of community college students, and the limitations of the one-shot instruction model. One respondent asserted that the Framework is "great for Harvard * $\mathrm{B}^{*} \mathrm{U}^{*} \mathrm{~T}^{*}$ not all schools are Harvard"; another contended, "The Framework has no bearing on the real world of community college librarianship.... When I worked at a university, I had the luxury of presenting some of the concepts in the Framework, but until they have the basics, they're sunk and so is the Framework." Other participants specifically mentioned the complex lives and educational needs of their community college students; as observed by one respondent, "most community colleges have open enrollment with under-prepared and under-represented populations. Academically and culturally, this often separates community colleges from their university level peers ... Often [the] basics feel left out of conversations around the Framework, it would be great for some examples of how to scale down the frames for such populations where they are the first to attend college or may have never owned a home computer." Finally, many respondents shared feelings of frustration regarding a disconnect between the Framework and the one-shot teaching model. "We teach one-shots almost exclusively," explained one librarian. "With such a short amount of time available with students, we can't really focus on abstract ideas-we need to devote too much time to nuts-and-bolts 'this is how you search' kind of lessons. It's frustrating, but I imagine it's similar at many CCs."

\section{Professional Development}

Nearly three-quarters of survey respondents $(73 \%, 874)$ report having participated in some form of professional development related to the Framework to date. Reading or skimming scholarly publications, trade publications, blogs, and listservs is the most frequent activity (61\%; 733), followed by sharing ideas and/or participating in discussions with colleagues at their community college library $(47 \%, 564)$, professional development for any academic librarian type $(39 \%, 467)$ and professional development specific to community college librarians $(21 \%, 225)$. Only 13 percent (156) have engaged in staff development provided by their community college library, and 8 percent (93) engaged with Framework materials as part of an LIS master's or doctoral program.

Substantial interest in participating in Framework continuing education was expressed. Seventy-three percent (869) reported an interest in participating in training related to the ACRL Framework geared toward librarians at both community colleges and four-year colleges and university, while 84 percent $(1,008)$ reported an interest in training geared toward community college librarians exclusively. See figure 3 for a summary of results.

Comments in an open-ended question speak to this desire for community college-specific professional development. One librarian pleaded, "Please facilitate community college-level interpretations and applications of the framework... CC Librarians in the trenches are starving for Framework support." Another explained, "It would be great to participate in a community college specific professional development that could break down the framework in a way that is comprehensive and meets the needs of libraries that tend to do one-shot research sessions. In my minimal exposure to the framework, I have found that it seems to make more 


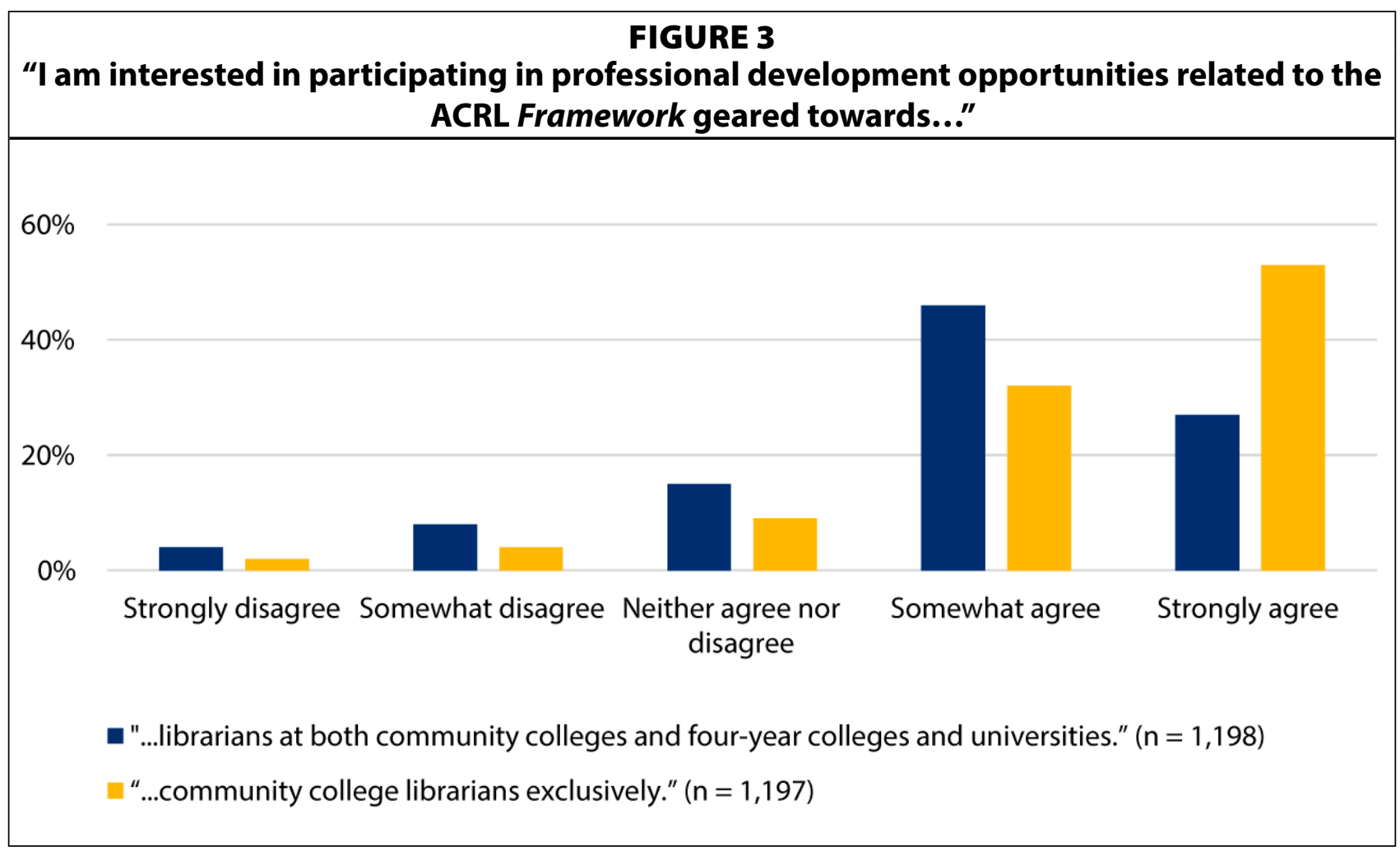

sense for lengthier courses and/or for four-year institutions that have more established liaison relationships with teaching faculty."

Respondents who have already participated in general professional development opportunities related to the Framework often report that these sessions did not meet their needs as community college librarians. One respondent shared this thought: "I've gone to several workshops to improve integration of the Framework into what we do at my college, but I don't feel as if I'm getting a lot of backup from ACRL and most of the work must be done on our own. Feeling a bit more support for community colleges would be greatly appreciated." Another disclosed that, "my turning point with the ACRL Framework was attending a training session presented by community college librarians. Up until that point, I was having a hard time seeing how it fit into what we do."

When survey data were examined by respondent subgroup, substantial interest was expressed across subgroups in both additional professional development and an adapted version of the Framework for a community college context; examined subgroups included those who are and are not library directors, are employed by colleges of varying sizes, and are and are not members of ACRL. Fully 75 to 82 percent of respondents within these subgroups were interested in an adapted version of the Framework, 58 to 88 percent were interested in additional professional development with librarians from two-year and fouryear institutions, and 82 to 88 percent were interested in additional professional development with librarians from two-year colleges exclusively. Of those who had not read the Framework and had not altered their instruction based on it, even 50 percent and 64 percent (respectively) were interested in an adapted version, 65 and 58 percent were interested in professional development with librarians from both institution types, and 69 and 73 percent were interested in professional development with librarians from two-year colleges exclusively. 


\section{Discussion}

This study represents the largest Framework implementation survey completed to date and is the first focused exclusively on community college librarians; the high number of completed responses $(1,201)$ signifies a strong interest in this line of inquiry. Findings have implications for future practice and research.

The high percent of respondents indicating they enjoy teaching information literacy would suggest that any issues community college librarians report about teaching with the Framework are unlikely to be related to feelings about teaching generally.

Engagement with and adoption of the Framework by two-year college librarians is not widespread and appears to lag behind that of the larger academic library community. Forty percent of respondents have not read the entire document, and only 11 percent strongly agreed that they are very familiar with its components. As of fall 2018, when the survey was fielded, 10 percent of survey respondents had altered their information literacy instruction "a great extent" as a result of the Framework. Though not directly comparable, this number is markedly lower than the Julien, Gross, and Latham study, which found that, by spring 2016, 31 percent of respondents across academic library types reported that the Framework has had a "significant influence" on them. ${ }^{26}$

One-shot instruction is a "quintessential" teaching scenario for academic librarians, ${ }^{27}$ and community college librarians deliver these sessions in high volumes. However, in introducing the Framework, ACRL specifically noted, "It is important for librarians and teaching faculty to understand that the Framework is not designed to be implemented in a single information literacy session in a student's academic career; it is intended to be developmentally and systematically integrated into the student's academic program at a variety of levels." ${ }^{28}$ This fundamental disconnect may be reflected in survey findings regarding a desire for professional development and a revision of the Framework.

Survey respondents exhibited substantial interest in professional development opportunities developed specifically for community college librarians. This programming could focus on implementing the Framework within the one-shot instructional model and on scaffolding frames to community college students new to libraries and research. Findings suggest that local, state, and national organizations will need to be mindful of the funding and staffing restrictions faced by many community college libraries and therefore may consider reduced cost cohort training programs and/or online learning modules. In addition to content on Framework-infused student learning outcomes, lesson plans, and assessments, community college librarians may also benefit from training on organizing and implementing Framework conversations with nonlibrary departments on campus.

Community college librarians are also very much interested in a version of the Framework document modified for community colleges. This adapted version might address perceptions of elitism within the existing Framework, the unique learning needs of community college students, and the limitations of the one-shot instruction model, which were highlighted as barriers to implementation for community college librarian respondents.

Results also indicate that community college library directors, deans, and department chairs may need to take a leadership role in facilitating local Framework incorporation. Teaching librarians may lack institutional support and motivation needed beyond individual drive. Survey respondents generally do not believe that integrating the Framework into their teaching practice has any significant impact on their advancement and promotion, nor do they feel 
that they have enough time to implement these changes. Community college library leadership may need to take the lead by giving community college librarians time to consider the Framework, including time for professional development opportunities, and ensuring that professional currency is considered as part of promotion and evaluation.

The data demonstrate that a majority of community college librarian study participants are not members of ACRL. This may be an impediment to Framework adoption; community college librarians may not be receiving information about the document as well as related workshops, webinars, and conferences. Low membership may be related to cost as well as community college librarian disenfranchisement from the larger academic library community.

\section{Limitations}

This study focuses only on the Framework-related behaviors and attitudes of academic librarians employed at two-year colleges; it does not examine Framework knowledge, use, and attitudes of academic librarians employed at four-year colleges and universities.

It also represents a single snapshot of a changing professional landscape. The Framework was adopted by the ACRL Board in January 2016, and the survey captured data in the fall of 2018. Engagement and implementation patterns could shift as the Framework becomes more mainstream within the IL community.

\section{Future Research}

One open-ended survey question asked respondents to identify the three words that best describe their feelings toward the ACRL Framework. These data will be analyzed and distributed in subsequent publications and/or conference proceedings.

Follow-up interviews to this survey have also been funded and occurred in spring 2019. A total of 18 community college librarians were interviewed by phone for approximately 60 minutes each. Interview questions delved into certain survey results in greater depth, particularly in the area of Framework adoption barriers and facilitators; professional development needs and potential modification of the Framework were also explored. Interviews were audio recorded and transcribed; interview transcripts were coded for emergence of themes.

Additional future research might also include longitudinal data collection of community college librarian familiarity, attitude, use, and feelings toward the Framework as well as a comparison of similar data with librarians employed at four-year institutions.

\section{Conclusion}

Community colleges are among the most diverse institutions in US higher education. Academic librarians who teach at these two-year schools face unique instructional challenges relative to their colleagues at four-year colleges and universities. The purpose of this survey was to explore community college librarian engagement with the ACRL Framework as related to familiarity, use, and attitude and to identify continuing education needs as related to their teaching practices and the Framework. Major study findings indicated limited integration of the Framework to date and an openness to future adoption with substantial interest in professional development and an adapted version of the Framework. If the Framework is recognized and accepted as a foundational tool for IL instruction in higher education, these results indicate that community college librarians may benefit from specialized and targeted opportunities to facilitate adoption and ultimately meet the unique needs of the community college student population. 


\section{Acknowledgments}

This project was made possible in part by the Institute of Museum and Library Services (RE97-18-0001-18). The authors gratefully acknowledge our Advisory Board: Dr. Braddlee, Craig Gibson, Dr. Debra Gilchrist, and Dr. Marie L. Radford. Thank you also to Kristine Brancolini and Marie Kennedy of the Institute for Research Design in Librarianship. 


\section{APPENDIX A. Carnegie Classifications Categories Included in Study Population}

Institutions classified by the National Center for Education Statistics (NCES) as two-year colleges within the following Carnegie Classifications were included in the study population.

- Associate's Colleges: High Career \& Technical-High Nontraditional

- Associate's Colleges: High Career \& Technical-High Traditional

- Associate's Colleges: High Career \& Technical-Mixed Traditional/Nontraditional

- Associate's Colleges: High Transfer-High Nontraditional

- Associate's Colleges: High Transfer-High Traditional

- Associate's Colleges: High Transfer-Mixed Traditional/Nontraditional

- Associate's Colleges: Mixed Transfer/Career \& Technical-High Nontraditional

- Associate's Colleges: Mixed Transfer/Career \& Technical-High Traditional

- Associate's Colleges: Mixed Transfer/Career \& Technical-Mixed Traditional/Nontraditional

- Baccalaureate/Associate's Colleges: Associate's Dominant

- Baccalaureate/Associate's Colleges: Mixed Baccalaureate/Associate's

- Special Focus Four-Year: Other Health Professions Schools

- Special Focus Four-Year: Other Special Focus Institutions

- Special Focus Four-Year: Other Technology-Related Schools

- Special Focus Two-Year: Arts \& Design

- Special Focus Two-Year: Health Professions

- Special Focus Two-Year: Other Fields

- Special Focus Two-Year: Technical Professions

- Tribal Colleges 


\section{APPENDIX B. The Survey Instrument}

\section{Q1}

Introduction to the Study:

We invite you to participate in a study of community college librarians. You have been selected for this study because you are employed as a librarian at a two-year college in the United States.

\section{Purpose:}

The purpose of this study is to explore the teaching practices of community college librarians. Your participation will allow us to better understand the continuing education needs of librarians like you. We hope to publish and present the results of this study.

\section{What Will Happen during the Study:}

We will ask you to click through a series of questions with options for response. Based on the instructions at the question level, you will choose one or multiple responses. The survey is Web-based and will take approximately 10 minutes to complete.

\section{Payment for Participation:}

By participating in the survey, you can enter a drawing to win one of three $\$ 100.00$ gift certificates to Amazon.com.

\section{Your Privacy Is Important:}

We will make every effort to protect your privacy. No sensitive information will be gathered as part of this survey. No personally identifying information will be kept with survey answers and/or interview responses. Survey data and interview response notes will be stored in a locked file cabinet located in the principal investigator's office for three years.

\section{Your Rights:}

Your participation in this study is completely voluntary, and no risks are anticipated for you as a result of participating. If you decide to be in the study, you will have the right to stop participating at any time.

\section{Institutional Review Board Approval:}

This study has been reviewed by the Institutional Review Board of Queensborough Community College and The City University of New York (CUNY) (Protocol 2018-0905). If you have any questions about your rights as a research participant in this study, please contact the CUNY Research Compliance Administrator at 646-664-8918 or email HRPP@cuny.edu.

\section{Questions, Comments or Concerns:}

If you have any questions, comments, or concerns about the research, you can talk to the following researcher:

Susan Wengler

Assistant Professor and Coordinator of Information Literacy

The Kurt R. Schmeller Library

Queensborough Community College 
swengler@qcc.cuny.edu

$718 / 281-5010$

If you have questions about your rights as a research participant, or you have comments or concerns that you would like to discuss with someone other than the researcher, please contact:

Dr. Linda Reesman

HRPP Coordinator

Queensborough Community College

lreesman@qcc.cuny.edu

$718 / 281-5253$

Alternately, you can contact:

CUNY Office of the Vice Chancellor for Research

Attn: Research Compliance Administrator

205 East 42nd Street

New York, NY 10017

In signing this consent form, I acknowledge receipt of a copy of this form; print a copy of this page for your records if desired.

If you agree with all of the above statements, provide your electronic signature by clicking on

"I agree" below; otherwise, click on "I do not agree" to opt out of this study.

$\square \quad$ I agree

$\square \quad$ I do not agree [If selected, respondent was disqualified]

Q2

Are you currently employed as a librarian in a two-year college in the United States?

Please note: "Two-year college" includes public and private community colleges, junior colleges, and technical colleges.

$\square \quad$ Yes

$\square \quad$ No [If selected, respondent was disqualified]

Q3

Is information literacy instruction part of your current job responsibilities?

$\square$ Yes

$\square$ No [If selected, respondent was disqualified]

Q4

Which of the following advanced degrees have you completed? Please select all that apply. [If neither of the first two options was selected, respondent was disqualified]

$\square$ Master's degree in library and information sciences (LIS)

$\square$ Doctorate degree in LIS

- Master's degree in non-LIS subject

$\square$ Doctorate degree in non-LIS subject

$\square \quad$ N/A (I have not completed an advanced degree) 
Please indicate the degree to which you agree or disagree with the following statement.

Q5

I enjoy teaching information literacy at my community college.

$\square$ Strongly disagree

$\square$ Somewhat disagree

$\square \quad$ Neither agree nor disagree

$\square$ Somewhat agree

$\square$ Strongly agree

Q6

Have you read the Association of College and Research Libraries (ACRL) Framework for Information Literacy for Higher Education (Framework)?

- Yes, I've read all of the Framework.

- Yes, I've read part of the Framework.

$\square$ No, I haven't read the Framework.

口 I'm not sure.

Q7

To what extent have you altered your information literacy instruction as a result of the ACRL Framework?

$\square \quad$ A great extent

$\square$ A moderate extent

$\square \quad$ A small extent

$\square \quad$ Not at all

Q8

Please indicate the degree to which you agree or disagree with the following statement. I am interested in integrating the Framework into my information literacy instruction. [Only displayed to respondents who have not incorporated the Framework]

$\square$ Strongly disagree

$\square$ Somewhat disagree

$\square \quad$ Neither agree nor disagree

$\square$ Somewhat agree

$\square$ Strongly agree

Please indicate the degree to which you agree or disagree with the following statements.

Q9

I am interested in further integrating the Framework into my information literacy instruction.

[Only displayed to respondents who have incorporated the Framework]

$\square$ Strongly disagree

$\square$ Somewhat disagree

$\square \quad$ Neither agree nor disagree

$\square$ Somewhat agree

$\square$ Strongly agree 
Q10

The ACRL Framework has improved my information literacy instruction. [Only displayed to respondents who have incorporated the Framework]

$\square$ Strongly disagree

$\square$ Somewhat disagree

$\square \quad$ Neither agree nor disagree

$\square$ Somewhat agree

$\square$ Strongly agree

\section{Q11}

Have you provided one-shot information literacy instruction to community college students in the last 12 months? Instruction can have taken place in person and/or online.

$\square$ Yes

Q12

When you provide one-shot information literacy instruction, how often do you use the ACRL Framework when you perform each of the following activities? [Only displayed to respondents who have provided one-shot instruction]

\begin{tabular}{|l|l|l|l|l|l|}
\hline & Never & Rarely & Sometimes & Often & $\begin{array}{l}\text { N/A (I don't perform } \\
\text { this activity when } \\
\text { I provide one-shot } \\
\text { instruction) }\end{array}$ \\
\hline Create student learning outcomes & & & & & \\
\hline Develop lesson plans & & & & & \\
\hline Design assessment tools & & & & & \\
\hline
\end{tabular}

\section{Q13}

Have you provided any of the following information literacy instruction to community college students in the last 12 months? Please select all that apply including in-person and online instruction.

$\square$ Multiple shots

$\square$ Credit-bearing

$\square$ Workshops

Other (please specify):

\section{Q14}

When you provide credit-bearing information literacy instruction, how often do you use the ACRL Framework when you perform each of the following activities? [Only displayed to respondents who have provided credit-bearing instruction]

\begin{tabular}{|l|l|l|l|l|l|}
\hline & Never & Rarely & Sometimes & Often & $\begin{array}{l}\text { N/A (I don't perform } \\
\text { this activity when } \\
\text { I provide credit- } \\
\text { bearing instruction) }\end{array}$ \\
\hline Create student learning outcomes & & & & & \\
\hline
\end{tabular}




\begin{tabular}{|l|l|l|l|l|l|}
\hline Develop lesson plans & & & & & \\
\hline Design assessment tools & & & & & \\
\hline
\end{tabular}

Please indicate the degree to which you agree or disagree with the following statements.

Q15

I am very familiar with the frames, knowledge practices, and dispositions in the ACRL Framework.

$\square \quad$ Strongly disagree

$\square$ Somewhat disagree

$\square \quad$ Neither agree nor disagree

$\square$ Somewhat agree

$\square$ Strongly agree

\section{Q16}

The ACRL Framework is relevant to information literacy instruction on community college campuses.

$\square$ Strongly disagree

$\square$ Somewhat disagree

$\square \quad$ Neither agree nor disagree

$\square$ Somewhat agree

$\square$ Strongly agree

\section{Q17}

I was satisfied with how the Framework was drafted, revised, introduced, and adopted by ACRL.

$\square \quad$ Strongly disagree

$\square$ Somewhat disagree

$\square \quad$ Neither agree nor disagree

$\square$ Somewhat agree

$\square$ Strongly agree

\section{Q18}

Incorporating the ACRL Framework into my information literacy instruction is important to advancement, promotion, or contract renewal in my current position.

$\square$ Strongly disagree

$\square$ Somewhat disagree

$\square \quad$ Neither agree nor disagree

$\square$ Somewhat agree

$\square \quad$ Strongly agree

\section{Q19}

Professional development opportunities related to the ACRL Framework adequately address my needs as a community college librarian.

$\square$ Strongly disagree 
$\square$ Somewhat disagree

$\square \quad$ Neither agree nor disagree

$\square$ Somewhat agree

$\square$ Strongly agree

Q20

I feel anxious about incorporating the ACRL Framework into my information literacy instruction.

$\square \quad$ Strongly disagree

$\square \quad$ Somewhat disagree

$\square \quad$ Neither agree nor disagree

$\square$ Somewhat agree

$\square \quad$ Strongly agree

Q21

I feel confident about incorporating the ACRL Framework into my information literacy instruction.

$\square \quad$ Strongly disagree

$\square \quad$ Somewhat disagree

$\square \quad$ Neither agree nor disagree

$\square$ Somewhat agree

$\square$ Strongly agree

Q22

I do not have enough time to adequately incorporate the ACRL Framework into my information literacy instruction.

$\square$ Strongly disagree

$\square$ Somewhat disagree

$\square \quad$ Neither agree nor disagree

$\square$ Somewhat agree

$\square$ Strongly agree

Q23

The time that it takes to integrate the ACRL Framework into information literacy instruction is worthwhile.

$\square$ Strongly disagree

$\square$ Somewhat disagree

$\square \quad$ Neither agree nor disagree

$\square$ Somewhat agree

$\square$ Strongly agree

\section{Q24}

It is easy to integrate the ACRL Framework into information literacy instruction.

$\square$ Strongly disagree

$\square$ Somewhat disagree

$\square \quad$ Neither agree nor disagree 
$\square$ Somewhat agree

$\square$ Strongly agree

\section{Q25}

The ACRL Framework has created opportunities for conversation outside the library with classroom faculty, administrators, and other staff at my community college.

Strongly disagree

$\square$ Somewhat disagree

$\square \quad$ Neither agree nor disagree

$\square$ Somewhat agree

$\square \quad$ Strongly agree

Q26

I would value a version of the ACRL Framework adapted for community colleges.

$\square$ Strongly disagree

$\square$ Somewhat disagree

$\square \quad$ Neither agree nor disagree

$\square$ Somewhat agree

$\square \quad$ Strongly agree

\section{Q27}

I currently rely on the rescinded ACRL Information Literacy Competency Standards for Higher Education in my information literacy instruction.

$\square \quad$ Strongly disagree

$\square$ Somewhat disagree

$\square \quad$ Neither agree nor disagree

$\square$ Somewhat agree

$\square \quad$ Strongly agree

\section{Q28}

I am interested in participating in professional development opportunities related to the ACRL Framework geared towards librarians at both community colleges and four-year colleges and universities.

$\square$ Strongly disagree

$\square$ Somewhat disagree

$\square \quad$ Neither agree nor disagree

$\square$ Somewhat agree

$\square$ Strongly agree

\section{Q29}

I am interested in participating in professional development opportunities related to the ACRL Framework geared towards community college librarians exclusively.

$\square$ Strongly disagree

$\square$ Somewhat disagree

$\square \quad$ Neither agree nor disagree 
$\square$ Somewhat agree

$\square$ Strongly agree

Q30

How important or unimportant are each of the following frames from the ACRL Framework for your information literacy instruction?

\begin{tabular}{|l|l|l|l|l|l|}
\hline & $\begin{array}{l}\text { Very } \\
\text { unimportant }\end{array}$ & $\begin{array}{l}\text { Somewhat } \\
\text { unimportant }\end{array}$ & $\begin{array}{l}\text { Neither } \\
\text { important nor } \\
\text { unimportant }\end{array}$ & $\begin{array}{l}\text { Somewhat } \\
\text { important }\end{array}$ & $\begin{array}{l}\text { Very } \\
\text { important }\end{array}$ \\
\hline $\begin{array}{l}\text { Authority Is Constructed and } \\
\text { Contextual }\end{array}$ & & & & & \\
\hline Information Creation as a Process & & & & & \\
\hline Information Has Value & & & & & \\
\hline Research as Inquiry & & & & & \\
\hline Scholarship as Conversation & & & & & \\
\hline Searching as Strategic Exploration & & & & & \\
\hline
\end{tabular}

\section{Q31}

How often do you reference the ACRL Framework in conversations with each of the following at your community college?

N/A (This does not exist at my college or I do not have conversations with

\begin{tabular}{|l|l|l|l|l|l|l|}
\multicolumn{2}{l}{ Never Rarely Sometimes Often Always them) } \\
\hline Classroom faculty & & & & & & \\
\hline Writing Center staff & & & & & & \\
\hline Center for Teaching \& Learning staff & & & & & & \\
\hline Curriculum committee(s) & & & & & & \\
\hline $\begin{array}{l}\text { Librarians, library administrators, } \\
\text { and library staff }\end{array}$ & & & & & & \\
\hline $\begin{array}{l}\text { Administrators (e.g. president, } \\
\text { provost, deans) }\end{array}$ & & & & & & \\
\hline Tutoring Center staff & & & & & & \\
\hline
\end{tabular}

\section{Q32}

What three words best describe your feelings toward the ACRL Framework? Please enter one word in each of the boxes below.

1.

2.

3.

Q33

Were you involved in the development and revision of the ACRL Framework in any of the following ways? Please select all that apply. 
$\square \quad$ Served as member of ACRL Task Force

- Serve(d) as member of Information Literacy Frameworks and Standards Committee

- Provided Framework draft feedback through formal channels (e.g. ACRL Task Force Framework feedback form, online hearing, in-person hearing)

- Provided Framework draft feedback through informal channels (e.g. listservs, social media, blogs, email)

$\square \quad$ Other (please specify):

\section{Q34}

Have you participated in any of the following professional development activities about the ACRL Framework? Please select all that apply.

- Reading or skimming scholarly publications, trade publications, blogs, listservs, etc.

$\square$ Sharing ideas and/or participating in discussions with colleagues at your community college library

- Staff development program(s) provided by your community college library

- Professional development specific to community college librarians (e.g. workshops, conference sessions)

- Professional development for any academic librarian type (e.g. workshops, conference sessions)

- Master's or doctoral degree LIS coursework

Other (please specify):

\section{Q35}

Have you produced any of the following work(s) related to the ACRL Framework? Please select all that apply.

$\square \quad$ Learning resources related to the Framework (e.g. lesson plans, LibGuides)

- Writing about the Framework through formal channels (e.g. scholarly publications, trade publications)

Writing about the Framework through informal channels (e.g. email, listservs)

- Presentation(s) about the Framework on my community college campus to library colleagues

- Presentation(s) about the Framework on my community college campus to non-library colleagues

- Presentation(s) about the Framework at conferences or workshops outside of my community college campus

$\checkmark \quad$ Other (please specify):

\section{Q36}

In what year did you graduate with your master's or doctoral degree in library and information sciences? If you have received multiple degrees in library and information sciences, please indicate the most recent year in which you graduated.

\section{Q37}

For how many years have you been a community college librarian? 
$\square \quad 3-5$ years

6-10 years

$\square 10+$ years

\section{Q38}

How many information literacy instruction sessions did you teach in the last 12 months? Please include all types of instruction (e.g. one-shots, multiple-shots, credit-bearing courses, workshops) that have taken place in person and/or online. For credit-bearing courses, please count each class meeting as a session.

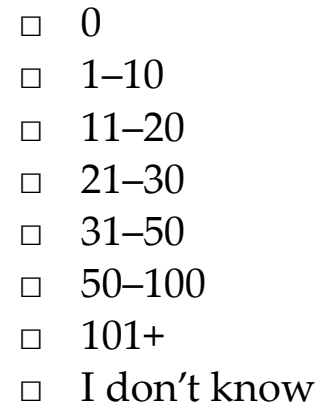

Q39

Which of the following best describes your employment status at your community college library?

$\square \quad$ Full-time librarian

$\square \quad$ Part-time librarian

$\square$ Other (please specify):

\section{Q40}

Which of the following best describes your current tenure status?

$\square$ Tenured

$\square$ Non-tenured and on a tenure track

$\square$ Non-tenured and not on a tenure track

$\square$ Other (please specify):

\section{Q41}

Are you currently a member of ACRL?
$\square \quad$ Yes
$\square \quad$ No
$\square$ Don't know/not sure

Q42

Are you a librarian dean, director, or chief officer?

$\square$ Yes

$\square \quad$ No 
Q43

Where is your community college located?

(Dropdown menu with 50 states, District of Columbia, and Puerto Rico)

\section{Q44}

Approximately how many full-time equivalent (FTE) students are enrolled on your college campus in the fall semester this year?

口 Less than 500 FTE students

500-1,999 FTE students

2,000-4,999 FTE students

口 5,000-9,999 FTE students

$\square \quad 10,000$ or more FTE students

Don't know/not sure

\section{Q45}

Has your community college library ever been the recipient of the ACRL Excellence in Academic Libraries Award-Community College Category?

$\square$ Yes

$\square \quad$ No

$\square$ Don't know/not sure

$\square$ Other (please specify):

\section{Q46}

Is there anything else you think we should know in order to better understand your experience with the ACRL Framework?

(Open response text box)

\section{Q47}

We will be conducting follow-up interviews to this survey via Skype during January 2019March 2019. Each interview participant will receive a $\$ 100$ gift certificate to Amazon.com. If you are interested in being contacted to learn more about possibly taking part in an interview, please provide your name and email address below. All contact information will remain completely confidential. If you agree to be contacted for a follow-up, you can always decline the request when contacted.

Name:

Email address: 


\section{APPENDIX C. Completed Surveys and Invitees by State}

\begin{tabular}{|c|c|c|c|c|}
\hline & Survey I & ndents & & \\
\hline & Frequency & Percentage & Frequency & Percentage \\
\hline California & 190 & $16 \%$ & 727 & $17 \%$ \\
\hline Texas & 130 & $11 \%$ & 472 & $11 \%$ \\
\hline New York & 101 & $9 \%$ & 345 & $8 \%$ \\
\hline Illinois & 73 & $6 \%$ & 281 & $6 \%$ \\
\hline North Carolina & 63 & $5 \%$ & 228 & $5 \%$ \\
\hline Arizona & 45 & $4 \%$ & 137 & $3 \%$ \\
\hline Massachusetts & 35 & $3 \%$ & 116 & $3 \%$ \\
\hline Pennsylvania & 35 & $3 \%$ & 143 & $3 \%$ \\
\hline New Jersey & 32 & $3 \%$ & 123 & $3 \%$ \\
\hline Michigan & 28 & $2 \%$ & 107 & $2 \%$ \\
\hline Ohio & 28 & $2 \%$ & 94 & $2 \%$ \\
\hline Oregon & 28 & $2 \%$ & 94 & $2 \%$ \\
\hline Virginia & 24 & $2 \%$ & 152 & $3 \%$ \\
\hline Maryland & 22 & $2 \%$ & 108 & $2 \%$ \\
\hline Tennessee & 21 & $2 \%$ & 65 & $1 \%$ \\
\hline Washington & 20 & $2 \%$ & 49 & $1 \%$ \\
\hline Florida & 19 & $2 \%$ & 30 & $1 \%$ \\
\hline Minnesota & 19 & $2 \%$ & 72 & $2 \%$ \\
\hline Mississippi & 18 & $2 \%$ & 75 & $2 \%$ \\
\hline Georgia & 17 & $1 \%$ & 88 & $2 \%$ \\
\hline lowa & 17 & $1 \%$ & 56 & $1 \%$ \\
\hline Wisconsin & 17 & $1 \%$ & 52 & $1 \%$ \\
\hline Louisiana & 16 & $1 \%$ & 43 & $1 \%$ \\
\hline South Carolina & 16 & $1 \%$ & 79 & $2 \%$ \\
\hline Missouri & 14 & $1 \%$ & 43 & $1 \%$ \\
\hline New Mexico & 14 & $1 \%$ & 40 & $1 \%$ \\
\hline Alabama & 13 & $1 \%$ & 78 & $2 \%$ \\
\hline Connecticut & 10 & $1 \%$ & 54 & $1 \%$ \\
\hline Kentucky & 10 & $1 \%$ & 49 & $1 \%$ \\
\hline Oklahoma & 9 & $1 \%$ & 43 & $1 \%$ \\
\hline Kansas & 8 & $1 \%$ & 47 & $1 \%$ \\
\hline Indiana & 7 & $1 \%$ & 12 & $0 \%$ \\
\hline Wyoming & 7 & $1 \%$ & 24 & $1 \%$ \\
\hline Arkansas & 6 & $1 \%$ & 42 & $1 \%$ \\
\hline New Hampshire & 5 & $0 \%$ & 11 & $0 \%$ \\
\hline Vermont & 5 & $0 \%$ & 10 & $0 \%$ \\
\hline Colorado & 4 & $0 \%$ & 24 & $1 \%$ \\
\hline Hawaii & 4 & $0 \%$ & 30 & $1 \%$ \\
\hline
\end{tabular}




\begin{tabular}{|c|c|c|c|c|}
\hline & Survey & ndents & & \\
\hline & Frequency & Percentage & Frequency & Percentage \\
\hline Idaho & 4 & $0 \%$ & 14 & $0 \%$ \\
\hline Maine & 4 & $0 \%$ & 16 & $0 \%$ \\
\hline Montana & 4 & $0 \%$ & 22 & $1 \%$ \\
\hline Utah & 4 & $0 \%$ & 9 & $0 \%$ \\
\hline Nevada & 3 & $0 \%$ & 4 & $0 \%$ \\
\hline Rhode Island & 3 & $0 \%$ & 23 & $1 \%$ \\
\hline Alaska & 1 & $0 \%$ & 1 & $0 \%$ \\
\hline Delaware & 1 & $0 \%$ & 1 & $0 \%$ \\
\hline Nebraska & 1 & $0 \%$ & 14 & $0 \%$ \\
\hline North Dakota & 1 & $0 \%$ & 10 & $0 \%$ \\
\hline District of Columbia & 0 & $0 \%$ & 0 & $0 \%$ \\
\hline Puerto Rico & 0 & $0 \%$ & 0 & $0 \%$ \\
\hline South Dakota & 0 & $0 \%$ & 5 & $0 \%$ \\
\hline West Virginia & 0 & $0 \%$ & 9 & $0 \%$ \\
\hline Guam & 0 & $0 \%$ & 1 & $0 \%$ \\
\hline Palau & 0 & $0 \%$ & 1 & $0 \%$ \\
\hline Total & 1,156 & $100 \%$ & 4,373 & $100 \%$ \\
\hline $\begin{array}{l}\text { Please note: The total } \\
\text { body of this article; the } \\
\text { to the distribution list }\end{array}$ & $\begin{array}{l}\text { vitees presen } \\
\text { es presented } \\
\text { vey was in th }\end{array}$ & $\begin{array}{l}\text { is table diffe } \\
\text { ody of the art }\end{array}$ & $\begin{array}{l}\text { ly from that } p \\
\text { taken into ace }\end{array}$ & $\begin{array}{l}\text { d within the } \\
\text { inor edits made }\end{array}$ \\
\hline
\end{tabular}

\section{Notes}

1. "Community College FAQs," Community College Research Center, available online at https://ccrc. tc.columbia.edu/Community-College-FAQs.html [accessed 15 January 2019].

2. Association of College and Research Libraries (ACRL), Information Literacy Competency Standards for Higher Education (2000), available online at www.ala.org/Template.cfm?Section=Home\&template=/ContentManagement/ ContentDisplay.cfm\&ContentID=33553 [accessed 15 January 2019]; ACRL, Framework for Information Literacy for Higher Education (2016), available online at www.ala.org/acrl/standards/ilframework [accessed 15 January 2019].

3. Kim Leeder Reed, "Square Peg in a Round Hole? The Framework for Information Literacy in the Community College Environment," Journal of Library Administration 55, no. 3 (Apr. 2015): 235-48, https://doi.org/10.1 080/01930826.2015.1034052.

4. Julia Bauder and Catherine Rod, "Crossing Thresholds: Critical Information Literacy Pedagogy and the ACRL Framework," College \& Undergraduate Libraries 23, no. 3 (Sept. 2016): 252-64, https://doi.org/10.1080/10691 316.2015.1025323; Colleen Burgess, “Teaching Students, Not Standards: The New ACRL Information Literacy Framework and Threshold Crossings for Instructors," Partnership: The Canadian Journal of Library E Information Practice \& Research 10, no. 1 (2015): 1-6, https://doi.org/10.21083/partnership.v10i1.3440; Rachel Wilder Gammons and Lindsay Taylor Inge, "Using the ACRL Framework to Develop a Student-Centered Model for Program-Level Assessment," Communications in Information Literacy 11, no. 1 (2017): 168-84, https://doi.org/10.15760/comminfolit.2017.11.1.40; Megan Oakleaf, "A Roadmap for Assessing Student Learning Using the New Framework for Information Literacy for Higher Education," Journal of Academic Librarianship 40, no. 5 (Sept. 2014): 510-14.

5. Andrew Battista et al., "Seeking Social Justice in the ACRL Framework," Communications in Information Literacy 9, no. 2 (2015): 111-25, https://doi.org/10.15760/comminfolit.2015.9.2.188; Christine Bombaro, "The Framework Is Elitist," Reference Services Review 44, no. 4 (2016): 552-63; Meredith Farkas, "Framework Freakout? Engaging with the Framework for Information Literacy," American Libraries 48, no. 9/10 (Sept. 2017): 54; Laura Saunders, "Connecting Information Literacy and Social Justice: Why and How," Communications in Information Literacy 11, no. 1 (2017): 55-75, available online at https://files.eric.ed.gov/fulltext/EJ1148869.pdf [accessed 15 January 2019]. 


\section{Community College Librarians and the ACRL Framework 95}

6. Battista et al., "Seeking Social Justice in the ACRL Framework."

7. Saunders, "Connecting Information Literacy and Social Justice."

8. Bombaro, "The Framework Is Elitist," 555, 556, 561, 552.

9. Heather Craven, "ACRL and Community College Libraries: We've Been Framed!" Community \& Junior College Libraries 22, no. 1/2 (2016): 3-5.

10. Megan Dempsey et al., "Continuing the Conversation: Questions about the Framework," Communications in Information Literacy 9, no. 2 (2015): 164-75.

11. Reed, "Square Peg in a Round Hole?" 246.

12. Troy Swanson, "Sharing the ACRL Framework with Faculty: Opening Campus Conversations," College and Research Library News 78, no. 1 (2017): 12-48.

13. Troy Swanson, "What's in a Name? Demonstrating Value through the ACRL Framework," Community and Junior College Libraries 22, no. 3/4 (2017): 83-85.

14. Stephanie Schulte and Maureen Knapp, "Awareness, Adoption, and Application of the Association of College \& Research Libraries (ACRL) Framework for Information Literacy in Health Sciences Libraries," Journal of the Medical Library Association 105, no. 4 (Oct. 2017): 347-54, available online at http://jmla.mlanet.org/ojs/jmla/ article/view/131/432 [accessed 15 January 2019].

15. Leslin Charles, "Embracing Challenges in Times of Change: A Survey of the Readiness of Academic Librarians in New Jersey for Transition to the ACRL Framework, Communications in Information Literacy 11, no. 1 (2017): 221-45, available online at www.comminfolit.org/index.php?journal=cil\&page=article\&op=view\&pat $\mathrm{h} \% 5 \mathrm{~B} \% 5 \mathrm{D}=\mathrm{v} 11 \mathrm{i1} \mathrm{p} 221 \&$ path $\% 5 \mathrm{~B} \% 5 \mathrm{D}=262$ [accessed 15 January 2019].

16. Charles, "Embracing Challenges in Times of Change," 226, 228.

17. Charles, "Embracing Challenges in Times of Change," 235.

18. Heidi Julien et al., "Survey of Information Literacy Instructional Practices in U.S. Academic Libraries," College E Research Libraries 79, no. 2 (Mar. 2018): 179-99, https://doi.org/10.5860/crl.79.2.179.

19. Melissa Gross et al., "What the Framework Means to Me: Attitudes of Academic Librarians toward the ACRL Framework for Information Literacy," Library and Information Science Research 40, no. 3/4 (2018): 262-68, https://doi.org/10.1016/j.lisr.2018.09.008.

20. Gross et al., "What the Framework Means to Me."

21. Gross et al., "What the Framework Means to Me."

22. Carlos Argüelles, "Information Literacy Instruction and Assessment in a Community College: A Collaborative Design," Community \& Junior College Libraries 21, no. 3/4 (2015): 81-99, available online at https://academicworks.cuny.edu/cgi/viewcontent.cgi?article $=1123 \&$ context=kb_pubs [accessed 15 January 2019]; Larissa Garcia, "Applying the Framework for Information Literacy to the Developmental Education Classroom," Community $\mathcal{E}$ Junior College Libraries 2, no. 1/2 (2014): 39-47.

23. Lynn Silipigni Connaway et al., Academic Library Impact: Improving Practice and Essential Areas to Research (Chicago, IL: Association of College and Research Libraries, 2017), 6, 111, available online at www.ala.org/acrl/ sites/ala.org.acrl/files/content/publications/whitepapers/academiclib.pdf [accessed 15 January 2019].

24. Tai Phan et al., Academic Libraries: 2012, NCES 2014-038 (Washington DC: U.S. Department of Education, National Center for Education Statistics, 2014), available online at http://nces.ed.gov/pubsearch [accessed 15 January 2019].

25. Paul Beatty and Gordon Willis, "Research Synthesis: The Practice of Cognitive Interviewing," Public Opinion Quarterly 71, no. 2 (Jan. 2007): 287-311, https://doi.org/10.1093/poq/nfm006.

26. Julien et al., "Survey of Information Literacy Instructional Practices in U.S. Academic Libraries."

27. Megan Oakleaf et al., "Notes from the Field," Communications in Information Literacy 6, no. 1 (2012): 5-23, available online at https://pdxscholar.library.pdx.edu/comminfolit/vol6/iss1/2/ [accessed 15 January 2019].

28. Association of College and Research Libraries, "Framework for Information Literacy Appendices," in Framework for Information Literacy for Higher Education, available online at www.ala.org/acrl/standards/ilframeworkapps [accessed 15 January 2019]. 